\title{
Protective role of trehalose during severe oxidative stress caused by hydrogen peroxide and the adaptive oxidative stress response in Candida albicans
}

\author{
Francisco J. Alvarez-Peral, ${ }^{1}$ Oscar Zaragoza, ${ }^{2} \dagger$ Yolanda Pedreño ${ }^{1}$ \\ and Juan-Carlos Argüelles ${ }^{1}$
}

1 Area de Microbiología, Facultad de Biología, Universidad de Murcia, Campus de Espinardo, E-30071 Murcia, Spain

2 Instituto de Investigaciones Biomédicas del CSIC, Unidad de Bioquímica y Genética de Levaduras, 28029 Madrid, Spain

\begin{abstract}
Author for correspondence: Juan-Carlos Argüelles. Tel: +34 9683671 31. Fax: +34968363963. e-mail: arguelle@um.es
\end{abstract}

The cellular response to the oxidative stress caused by hydrogen peroxide and its putative correlation with the stress protector trehalose was investigated in Candida albicans CAI.4 and the tps1/tps1 double mutant, which is deficient in trehalose synthesis. When exponential wild-type blastoconidia were exposed to high concentrations of hydrogen peroxide, they displayed a high cell survival, accompanied by a marked rise of intracellular trehalose. The latter is due to a moderate activation of trehalose synthase and the concomitant inactivation of neutral trehalase. Identical challenge in the tps1/tps1 double mutant severely reduced cell viability, a phenotype which was suppressed by overexpression of the TPS1 gene. Pretreatment of growing cultures from both strains with either a low, non-lethal concentration of $\mathrm{H}_{2} \mathrm{O}_{2}(0.5 \mathrm{mM})$ or a preincubation at $37{ }^{\circ} \mathrm{C}$, induced an adaptive response that protected cells from being killed by a subsequent exposure to oxidative stress. During these mild oxidative preincubations, trehalose was not induced in CAI.4 cells and remained undetectable in their tps1/tps1 counterpart. Blastoconidia from the two strains exhibited a similar degree of cell protection during the adaptive response. The induction of trehalose accumulation by $\mathrm{H}_{2} \mathrm{O}_{2}$ was not due to an increased expression of TPS1 mRNA. These results are consistent with a mainly protective role of trehalose in C. albicans during direct oxidative stress but not during acquired oxidative tolerance.

Keywords: TPS1, cell protector, oxidative stress, adaptive response, opportunistic yeast pathogen

\section{INTRODUCTION}

In aerobically growing organisms, the formation of reactive oxygen species (ROS) including the superoxide anion $\left(\mathrm{O}_{2}^{-}\right)$, hydrogen peroxide $\left(\mathrm{H}_{2} \mathrm{O}_{2}\right)$ and the hydroxyl radical $\left(\mathrm{OH}^{*}\right)$ is the consequence of oxidative metabolism or is caused by the addition of external agents. The toxic effects of ROS are crucial in the destruction of

Present address: Albert Einstein College of Medicine, Microbiology and Immunology. Golding Building, room 701, 1300 Morris Park Avenue, Bronx, NY 10461, USA

Abbreviations: ROS, reactive oxygen species; T-6P synthase, trehalose-6phosphate synthase. intracellular pathogens by macrophages and reflect the ability to damage essential cellular components such as nucleic acids, lipids and proteins (Storz et al., 1987; Jamieson, 1998; Estruch, 2000). Furthermore, the oxidative perturbations caused by ROS on the body's own cells have been associated with important human diseases and ageing, e.g. Parkinson's, diabetes or lateral sclerosis (Berlett \& Stadtman, 1997). To circumvent the harmful nature of ROS, many organisms have evolved specific defence mechanisms, which involve the synthesis and/or activation of protective enzymes or molecules (Mager \& Moradas-Ferreira, 1993; Jamieson, 1998; Estruch, 2000).

Yeast cells represent a very convenient model for studying cellular responses to oxidants and other 
physiological stresses. In this lower eukaryote, accumulation of the non-reducing disaccharide trehalose has been convincingly demonstrated as one of the main defence mechanisms against different stress conditions, such as heat shock, nutrient starvation, dehydration, toxic chemicals and oxidative stress (Wiemken, 1990; Thevelein, 1996; Estruch, 2000; Argüelles, 2000). Trehalose seems to act by stabilizing membranes and native proteins as well as by suppressing the aggregation of denatured proteins (Singer \& Lindquist, 1998). The expression of genes encoding trehalose-6-phosphate synthase (TPS1) and neutral trehalase (NTH1) is induced in response to specific stress challenges (Nwaka et al., 1995; Nwaka \& Holzer, 1998; Zähringer et al., 1997, 2000).

In this study, we investigate the role of trehalose as a specific cellular protector against oxidative stress in the opportunistic yeast pathogen Candida albicans, a ubiquitous human commensal in healthy people. However, among the immunocompromised population, C. albicans behaves as a highly virulent pathogen and invasive candidiasis is frequent in AIDS patients, transplant recipients, neonates and those undergoing cancer or antibiotic therapy (Cutler, 1991; Coleman et al., 1993; Odds, 1988, 1994). In addition, C. albicans is a dimorphic fungus that can grow either as budding yeast cells (blastoconidia) or as mycelium (hypha and/or pseudohypha) (Shepherd et al., 1985; Odds, 1988; Cutler, 1991; Molero et al., 1998; Brown \& Gow, 1999). Morphological transition is a contributory factor in pathogenesis, the mycelial phase being predominant during host tissue colonization. However, many underlying signals that govern morphogenesis remain to be elucidated (Lo et al., 1997; Brown \& Gow, 1999; Ernst, 2000). Previous studies on trehalose metabolism in $C$. albicans indicate that neither its accumulation in blastoconidia nor its further hydrolysis is essential for the yeast-to-hypha dimorphic conversion (Zaragoza et al., 1998; Argüelles et al., 1999). However, trehalose storage confers thermotolerance on exponentially growing cells (Argüelles, 1997). According to the results presented here, the disaccharide protects cells against drastic oxidative stress, but is not required for the adaptive oxidative stress response, a process that might be relevant in the course of an in vivo infection.

\section{METHODS}

Yeast and bacterial strains, culture conditions and molecular biology procedures. The strain Candida albicans CAI.4 (ura3::imm-434/ura-3::imm-434) (TPS1) (Fonzi \& Irwin, 1993) and its isogenic trehalose-deficient derivative (tps1/tps1) (Zaragoza et al., 1998) were used throughout. A new strain LOZ253 (tps1/tps1 + pTPS1) was obtained by reintroduction of the CaTPS1 gene into the tps1/tps1 mutant. For this purpose, plasmid POZ4 was constructed as follows: a $4 \mathrm{~kb}$ fragment EcoRI (blunt-ended)-HindIII from plasmid pOZ1-2 [a derivative of pOZ1-1, lacking the $2.5 \mathrm{~kb} \mathrm{XbaI}$ fragment (Zaragoza et al., 1998)], was cloned into the C. albicans vector pRM1 (Plá et al., 1995) digested with PstI (blunt-ended) and HindIII. Transformation of C. albicans was performed according to Kurtz et al. (1986), and colonies were selected on $2 \%$ agar plates containing $0.17 \%$ Yeast Nitrogen Base (YNB, Difco), $0.5 \%$ ammonium sulphate and $2 \%$ galactose.

Yeast cell cultures were grown at $28{ }^{\circ} \mathrm{C}$ by shaking in a medium consisting of $2 \%$ peptone, $1 \%$ yeast extract and $2 \%$ galactose (YPgal). The strains were maintained by periodic subculturing on solid YPgal. Escherichia coli DH5 $\alpha$ transformation and recombinant DNA manipulation followed standard procedures (Sambrook et al., 1989).

Oxidative stress treatments and acquired oxidative stress tolerance. Cultures were grown in YPgal until the exponential phase $\left(\mathrm{OD}_{600}=0 \cdot 8-1 \cdot 3\right)$ and then divided into several identical aliquots, which were treated with different $\mathrm{H}_{2} \mathrm{O}_{2}$ concentrations (or maintained without $\mathrm{H}_{2} \mathrm{O}_{2}$ as a control) and incubated at $28{ }^{\circ} \mathrm{C}$ for $1 \mathrm{~h}$. For experiments on acquired oxidative tolerance or 'cross-tolerance', a given sample was incubated with $0.5 \mathrm{mM} \mathrm{H} \mathrm{O}_{2}$ or at $37^{\circ} \mathrm{C}$ for $1 \mathrm{~h}$ and immediately challenged with $50 \mathrm{mM} \mathrm{H}_{2} \mathrm{O}_{2}$. Viability was determined after appropriate dilution of the samples with sterile water by plating in triplicate on solid YPgal. Between 30 and 300 colonies were counted per plate. Survival was normalized to control samples $(100 \%$ viability).

Preparation of permeabilized cells and cell-free extracts. At the indicated times, aliquots were harvested, washed and resuspended at known densities (usually 10-15 $\mathrm{mg} \mathrm{ml}^{-1}$, wet weight) in $10 \mathrm{mM}$ MES buffer $\mathrm{pH} 6.0$. For the measurement of acid trehalase, these samples were treated with $10 \%(\mathrm{v} / \mathrm{v})$ of a mixture composed of toluene/ethanol/Triton X-100 (TET; $1: 4: 0 \cdot 2$ by vol.). The suspension was shaken in a vortex for $5 \mathrm{~min}$ at $4{ }^{\circ} \mathrm{C}$, washed and resuspended at initial density in $10 \mathrm{mM}$ MES pH 6.0.

Neutral trehalase and trehalose-6-phosphate synthase (T-6P synthase) activities of cell-free extracts were determined as described previously (Argüelles et al., 1999), except that no $\mathrm{CaCl}_{2}$ was included in the extraction buffer $(10 \mathrm{mM} \mathrm{MES}$, $\mathrm{pH} \mathrm{6.0).}$

Enzymic assays. Acid trehalase was assayed by incubating $50 \mu \mathrm{l}$ permeabilized cells $(0 \cdot 5-1 \cdot 0 \mathrm{mg}$ wet weight) with $200 \mu \mathrm{l}$ $200 \mathrm{mM}$ trehalose prepared in $100 \mathrm{mM}$ sodium acetate $\mathrm{pH} 5 \cdot 6$. The assay for neutral trehalase contained $50 \mu \mathrm{l}$ cell-free extract (25-100 $\mu$ g protein) and $200 \mu \mathrm{l} 200 \mathrm{mM}$ trehalose prepared in $25 \mathrm{mM}$ MES $\mathrm{pH} 7 \cdot 1,125 \mu \mathrm{M} \mathrm{CaCl}_{2}$. The reactions were incubated at $37^{\circ} \mathrm{C}$ for $15-30 \mathrm{~min}$ and stopped by heating in a water bath at $100{ }^{\circ} \mathrm{C}$ for $5 \mathrm{~min}$. The glucose released was determined using the glucose oxidase-peroxidase method. One unit of trehalase is defined as the amount of enzyme that hydrolyses $1 \mu \mathrm{mol}$ trehalose $(2 \mu \mathrm{mol}$ glucose $)$ per min. Specific activity is expressed either as $\mathrm{mU}(\mathrm{mg} \text { wet weight })^{-1}$ (external trehalase) or as $\mathrm{mU}(\mathrm{mg} \text { protein })^{-1}$ (neutral trehalase).

T-6P synthase was measured at $40{ }^{\circ} \mathrm{C}$ in the supernatants of cell-free extracts as described by Argüelles (1997). Specific activity is expressed as $\mathrm{mU}(\mathrm{mg} \text { protein })^{-1}$.

Other determinations. Intracellular trehalose was extracted from $20-50 \mathrm{mg}$ yeast samples in $2 \mathrm{ml}$ boiling water and the concentration measured with commercial trehalase (Sigma) following the method described by Blázquez et al. (1994), except that glucose was estimated by the glucose oxidaseperoxidase procedure. Parallel controls were run to correct for the basal levels of glucose.

Growth was monitored by measuring the $\mathrm{OD}_{600}$ of cultures or by direct cell counting with a haemocytometer; at least 200 
colonies were counted for each determination. Protein was estimated by the Lowry method with BSA as standard.

\section{RESULTS}

\section{Level of cell viability and trehalose content after oxidative stress by $\mathrm{H}_{2} \mathrm{O}_{2}$}

Because the capacity of the trehalose-deficient mutant tps1/tps1 to grow on exogenous glucose and fructose as carbon source is seriously compromised (Zaragoza et al., 1998), all the experiments were carried out in YPgal medium. In addition, early exponential phase yeast cells were used throughout this study as they exhibit higher sensitivity to a variety of stress treatments than resting cultures (Werner-Washburne et al., 1993; Jamieson et al., 1996; Jamieson, 1998). In an initial set of experiments, we analysed the degree of cell killing caused by several stress treatments (e.g. heat shock, saline and $\mathrm{H}_{2} \mathrm{O}_{2}$ exposures) in both the wild-type CAI.4 strain and the isogenic tps $1 /$ tps 1 mutant. Both strains exhibited almost $100 \%$ survival after being subjected for $2 \mathrm{~h}$ to $42{ }^{\circ} \mathrm{C}$ or $300 \mathrm{mM}$ sodium chloride (not shown). By contrast, CAI.4 cells displayed a weak sensitivity to $25 \mathrm{mM} \mathrm{H}_{2} \mathrm{O}_{2}$ (Fig. 1a), whereas viability of the tps1/tps1 mutant was drastically reduced by this oxidative treatment (Fig. 1a). The cell survival was restored by reintroduction of the TPS1 gene in a tps1/tps1 background (Fig. 1a).

When logarithmic blastoconidia from both strains were subjected to increasing concentrations of $\mathrm{H}_{2} \mathrm{O}_{2}$, only tps1/tps1 cells suffered a marked loss of cell viability compared to wild-type cultures (Fig. 1b). As has been noted previously, C. albicans displays a much greater natural resistance to $\mathrm{H}_{2} \mathrm{O}_{2}$ than the budding yeast Saccharomyces cerevisiae (Jamieson et al., 1996; Jamieson, 1998).

Whether there is a correlation between the resistance of CAI.4 cells and their endogenous trehalose content has also been determined. The oxidative challenge promoted a significant rise in trehalose in CAI.4 cells (Table 1), but failed to induce any trehalose increase in the $t p s 1 / t p s 1$ mutant counterpart (Table 1). However, survival of both strains upon $\mathrm{H}_{2} \mathrm{O}_{2}$ exposure did not exactly mirror parallel changes in the intracellular trehalose content (Fig. 1b, Table 1). The trehalose accumulation in CAI.4 cultures was the result of the T-6P synthase activation (TPS1p) and the concomitant inactivation of neutral trehalase (NTH1p), the latter being the enzyme responsible for trehalose mobilization in response to different physiological signals (Thevelein, 1996; Zähringer et al., 1997; Argüelles, 2000) (Table 1). The presence of cycloheximide had a slight inhibitory effect on the oscillations recorded in both enzymic activities (results not shown). Overexpression of the TPS1 gene suppressed the susceptibility of tps1/tps 1 cells to oxidative stress treatments (Fig. 1b) and restored intracellular trehalose levels (Table 2 ). These data provide additional evidence that CaTPS1p is the sole activity involved in trehalose biosynthesis in C. albicans (Zaragoza et al., 1998).
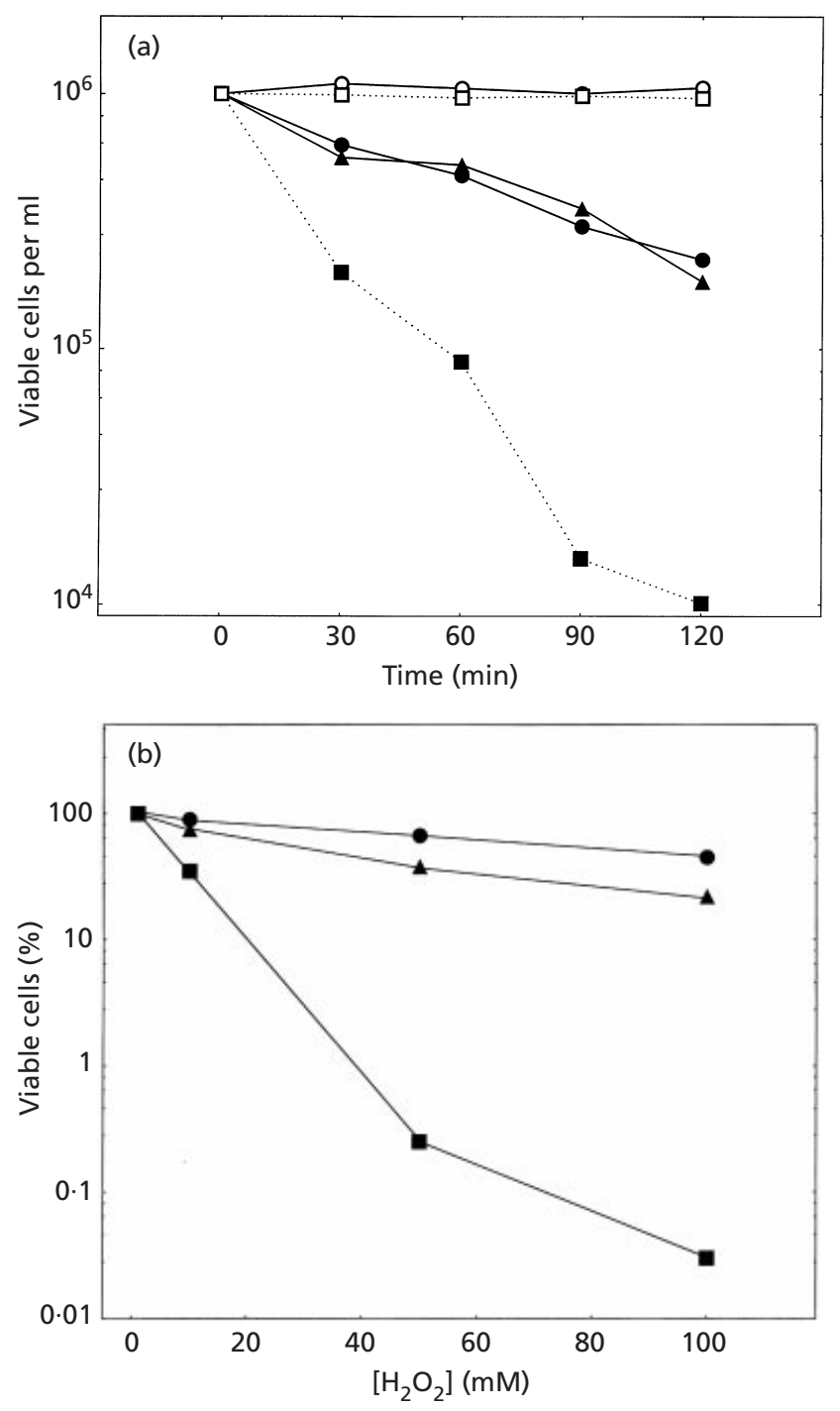

Fig. 1. Effect of oxidative stress treatment on $C$. albicans cellular survival. (a) Cell killing caused by addition of $\mathrm{H}_{2} \mathrm{O}_{2}$. The following strains were used: CAI.4 (wild-type) (0), tps1/tps, a trehalose-deficient mutant ( $\boldsymbol{\square}$ ) and LOZ253 (tps1/tps1+pTPS1) (A). Yeast cells were grown in YPgal until the exponential phase $\left(\mathrm{OD}_{600} 0.8-1 \cdot 2\right)$, adjusted to a cellular density of 1.0 $1.2 \times 10^{6}$ cells $\mathrm{ml}^{-1}$ and treated for $120 \mathrm{~min}$ with $25 \mathrm{mM} \mathrm{H}_{2} \mathrm{O}_{2}$. Untreated control CAI.4 ( $\bigcirc)$ and tps1/tps1 ( $\square$ ) samples, were maintained at $28^{\circ} \mathrm{C}$. (b) Effect of increasing concentrations of $\mathrm{H}_{2} \mathrm{O}_{2}$ on the cell viability. The same $C$. albicans strains were grown as in (a) and then exposed to different concentrations of $\mathrm{H}_{2} \mathrm{O}_{2}$ for $60 \mathrm{~min}$. In both experiments, the assays were repeated three times with consistent results. Error bars were omitted for the sake of clarity, but the standard deviation was lower than $12 \%$. Representative results are shown.

\section{Changes in trehalose content during the adaptive response to oxidative stress}

The addition of $0.5 \mathrm{mM} \mathrm{H}_{2} \mathrm{O}_{2}$ to actively growing cells of CAI.4, tps1/tps1 and LOZ253 (tps1/tps1+pTPS1) strains had little or no effect on cell viability. By contrast, $50 \mathrm{mM} \mathrm{H}_{2} \mathrm{O}_{2}$ produced a rapid and pronounced re- 
Table 1. Intracellular content of trehalose and the activities of trehalose synthase, and neutral and acid trehalases in exponential cultures of C. albicans wild-type (CAl.4) and tps1/tps1 mutant after addition of increasing concentrations of $\mathrm{H}_{2} \mathrm{O}_{2}$ for 60 min

Yeast cells were grown at $28^{\circ} \mathrm{C}$ in YPgal medium until they reached exponential phase $\left(\mathrm{OD}_{600} 0 \cdot 8-1 \cdot 0\right)$. The samples were prepared and the trehalose content and enzymic activities measured as described in Methods.

Numbers in parentheses represent the relative activity normalized to the control for each parameter, taking the control treatment as $1 \cdot 0$.

\begin{tabular}{|c|c|c|c|c|c|c|c|c|}
\hline \multirow[t]{2}{*}[\mathrm{H}_{2}\mathrm{O}_{2}]{$(\mathrm{mM})$} & \multicolumn{2}{|c|}{ Trehalose $\mathrm{e}^{*}$} & \multicolumn{2}{|c|}{ T-6P synthase $†$} & \multicolumn{2}{|c|}{ Neutral trehalase $\neq$} & \multicolumn{2}{|c|}{ Acid trehalase $\mathbb{S}$} \\
\hline & CAI.4 & tps $1 / t p s 1$ & CAI.4 & tps $1 /$ tps 1 & CAI.4 & tps $1 / \operatorname{tps} 1$ & CAI.4 & tps $1 /$ tps 1 \\
\hline 0 & $3 \cdot 5(1 \cdot 0)$ & $1 \cdot 6$ & $14 \cdot 8(1 \cdot 0)$ & $<2 \cdot 0$ & $26 \cdot 6(1 \cdot 0)$ & $21 \cdot 1(1 \cdot 0)$ & $5 \cdot 9(1.0)$ & $6.5(1.0)$ \\
\hline 2 & $4 \cdot 1(1 \cdot 2)$ & $1 \cdot 8$ & $17 \cdot 3(1 \cdot 2)$ & $<2 \cdot 0$ & $23 \cdot 7(0 \cdot 9)$ & $19 \cdot 3(0 \cdot 9)$ & $6 \cdot 1(1 \cdot 0)$ & $7 \cdot 7(1 \cdot 2)$ \\
\hline 10 & $6 \cdot 8(1.9)$ & $1 \cdot 4$ & $23 \cdot 7(1 \cdot 6)$ & $<2 \cdot 0$ & $15 \cdot 8(0 \cdot 6)$ & $17 \cdot 6(0 \cdot 8)$ & $7 \cdot 9(1 \cdot 3)$ & $6 \cdot 8(1 \cdot 0)$ \\
\hline 25 & $9 \cdot 5(2 \cdot 7)$ & $1 \cdot 5$ & $30 \cdot 2(2 \cdot 0)$ & $<2 \cdot 0$ & $12 \cdot 2(0 \cdot 5)$ & $14 \cdot 8(0 \cdot 7)$ & $5 \cdot 2(0 \cdot 9)$ & $4.9(0.7)$ \\
\hline 50 & $11(3 \cdot 1)$ & $1 \cdot 7$ & $27 \cdot 6(1.9)$ & $<2 \cdot 0$ & $5 \cdot 3(0 \cdot 2)$ & $12 \cdot 3(0 \cdot 6)$ & $5 \cdot 0(0 \cdot 8)$ & $2 \cdot 8(0 \cdot 4)$ \\
\hline 100 & $2 \cdot 9(0 \cdot 8)$ & $1 \cdot 4$ & $12 \cdot 5(0 \cdot 8)$ & $<2 \cdot 0$ & $4 \cdot 7(0 \cdot 2)$ & $11 \cdot 4(0 \cdot 5)$ & $4 \cdot 3(0 \cdot 7)$ & $2 \cdot 2(0 \cdot 3)$ \\
\hline
\end{tabular}

* nmol trehalose $(\mathrm{mg} \text { wet } \mathrm{wt})^{-1}$.

† nmol trehalose $\min ^{-1}(\mathrm{mg} \text { protein })^{-1}$.

$\ddagger$ nmol glucose $\min ^{-1}$ (mg protein $)^{-1}$.

$\$$ nmol glucose $\min ^{-1}(\mathrm{mg} \text { wet } \mathrm{wt})^{-1}$.

Table 2. Intracellular content of trehalose during the adaptive response to oxidative stress in C. albicans

Exponential blastoconidia of CAI.4, tps $1 /$ tps 1 and LOZ253 $(t p s 1 / t p s 1+\mathrm{pTPS} 1)$ strains $\left(\mathrm{OD}_{600} 0 \cdot 8-1 \cdot 2\right)$ were preincubated for $1 \mathrm{~h}$ with $0.5 \mathrm{mM} \mathrm{H}_{2} \mathrm{O}_{2}$ and immediately challenged with $50 \mathrm{mM} \mathrm{H}_{2} \mathrm{O}_{2}$ or directly submitted to oxidative stress. Samples for trehalose determination were harvested after $60 \mathrm{~min}$ treatment. For other details see Fig. 2.

Numbers in parentheses represent the activity normalized to the control for each parameter, taking the control treatment as $1 \cdot 0$.

\begin{tabular}{|lrrr|}
\hline \multirow{2}{*}{ Treatment } & \multicolumn{3}{c|}{ Trehalose $\left[\right.$ nmol $\left.(\mathbf{m g} \text { wet wt })^{-1}\right]$} \\
\cline { 2 - 4 } & CAI.4 & tps $1 /$ tps 1 & LOZ253 \\
\hline Control & $3 \cdot 1(1 \cdot 0)$ & $1 \cdot 3(1 \cdot 0)$ & $2 \cdot 8(1 \cdot 0)$ \\
$\mathrm{H}_{2} \mathrm{O}_{2}(0 \cdot 5 \mathrm{mM})$ & $2 \cdot 9(0 \cdot 9)$ & $1 \cdot 1(0 \cdot 8)$ & $2 \cdot 9(1 \cdot 0)$ \\
$\mathrm{H}_{2} \mathrm{O}_{2}(0 \cdot 5 \rightarrow 50 \mathrm{mM})$ & $8 \cdot 1(2 \cdot 6)$ & $1 \cdot 5(1 \cdot 1)$ & $9 \cdot 5(3 \cdot 4)$ \\
$\mathrm{H}_{2} \mathrm{O}_{2} 50 \mathrm{mM}$ & $11 \cdot 8(3 \cdot 8)$ & $1 \cdot 8(1 \cdot 4)$ & $8 \cdot 7(3 \cdot 1)$ \\
\hline
\end{tabular}

duction in the fraction of viable cells (Fig. 2). When these cultures were treated with $0.5 \mathrm{mM} \mathrm{H}_{2} \mathrm{O}_{2}$ for $1 \mathrm{~h}$ and then immediately challenged with $50 \mathrm{mM} \mathrm{H}_{2} \mathrm{O}_{2}$, they acquired a significant degree of resistance (Fig 2). This resistance was similar, albeit slightly lower, in the mutant overexpressing the TPS1 gene than in the corresponding wild-type strain. Parallel measurements of intracellular trehalose revealed that wild-type cells accumulated large amounts of the disaccharide with this severe stress $\left(50 \mathrm{mM} \mathrm{H}_{2} \mathrm{O}_{2}\right)$ as well as during the adaptive response to oxidative treatment $(0 \cdot 5 \rightarrow 50 \mathrm{mM}$ $\left.\mathrm{H}_{2} \mathrm{O}_{2}\right)$, whereas low $\mathrm{H}_{2} \mathrm{O}_{2}$ levels $(0.5 \mathrm{mM})$ did not trigger trehalose storage (Table 2). As expected, the low basal level of trehalose in tps1/tps1 cells was never modified by further $\mathrm{H}_{2} \mathrm{O}_{2}$ exposure (Table 2). Indeed, the improvement in cell recovery induced by low levels of $\mathrm{H}_{2} \mathrm{O}_{2}$ in this trehalose-deficient mutant must be independent of the protective role played by the carbohydrate.

'Cross-tolerance' has been demonstrated previously in $S$. cerevisiae, where tolerance to one type of stress confers cross-protection to another stress (Lewis et al., 1995, 1997). Therefore, we investigated whether thermotolerance-inducing treatments, which have always been associated with trehalose storage (Hottiger et al., 1987; Thevelein, 1996), would confer oxidative protection in C. albicans. As has been demonstrated for other C. albicans strains (Argüelles, 1997), exponential CAI.4 and $t p s 1 / t p s 1$ cultures incubated at $28^{\circ} \mathrm{C}$ underwent a dramatic viability reduction when submitted to a severe heat stress $\left(52.5^{\circ} \mathrm{C}\right.$ for $\left.5 \mathrm{~min}\right)$. Preincubation of equivalent samples at standard human body temperature $\left(37^{\circ} \mathrm{C}\right)$ led to a substantial increase of cells from both strains able to withstand the further heat shock (threeto fivefold for CAI.4 and two- to threefold for tps $1 / t_{p s} 1$, respectively, data not shown). By contrast, basal level of trehalose in CAI. 4 growing cultures at $28^{\circ} \mathrm{C}$ was very low and not increased by mild heat exposure at $37^{\circ} \mathrm{C}$, while trehalose was virtually nil in the $t p s 1 / t p s 1$ mutant (Table 3). Remarkably, trehalose synthesis in C. albicans seems to be markedly temperature-dependent, since no trehalose accumulation was observed upon incubation at $37^{\circ} \mathrm{C}$ (Zaragoza et al., 1998; Table 3), although a 


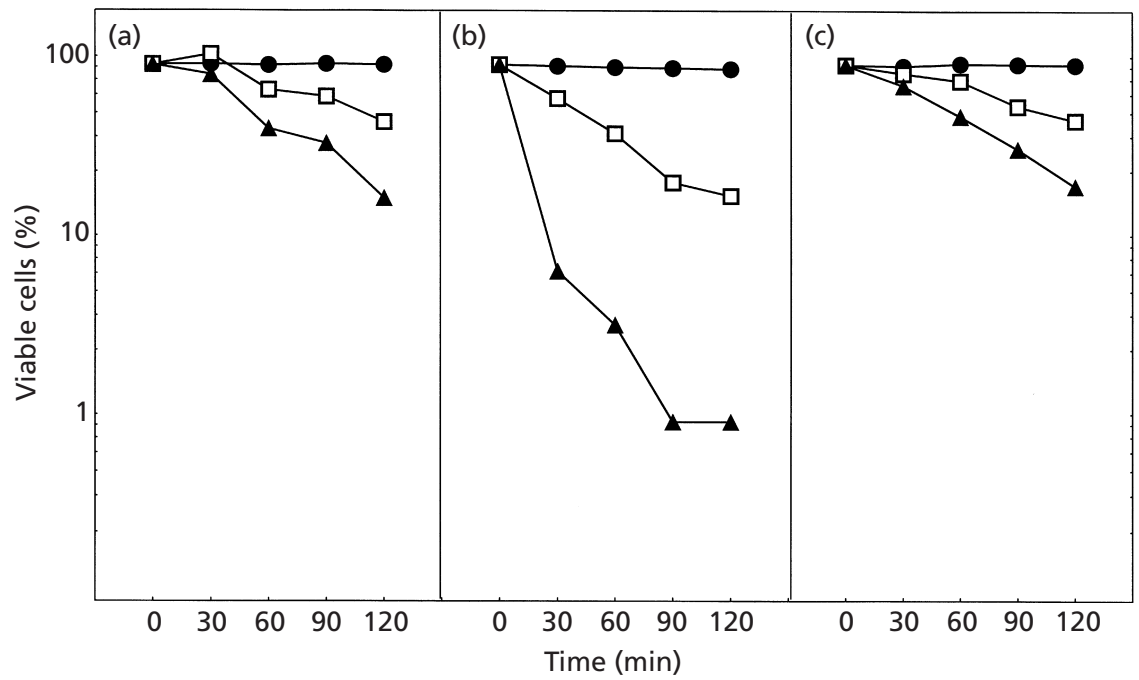

Fig. 2. Adaptive oxidative stress response in C. albicans. The strains CAI.4 (a), tps1/tps1 (b) and LOZ253 (c) were grown in YPgal until they reached exponential phase $\left(\mathrm{OD}_{600} 0 \cdot 8-1 \cdot 2\right)$. They were divided into three identical aliquots and treated for 60 min with $0.5 \mathrm{mM} \mathrm{H}_{2} \mathrm{O}_{2}(0) ; 50 \mathrm{mM} \mathrm{H}_{2} \mathrm{O}_{2}(\boldsymbol{\Lambda})$ or preincubated with $0.5 \mathrm{mM}$ for 60 min and immediately exposed to $50 \mathrm{mM} \mathrm{H} \mathrm{O}_{2}$ during the same time ( $\square$ ). Samples were harvested for cellular viability at the indicated periods. The experiments were repeated three times with consistent results. Standard deviation was lower than $12 \%$. Results from a representative experiment are shown.

Table 3. Changes in trehalose content and the enzymic activities of trehalose synthase and neutral trehalase during the adaptive cross-tolerance to oxidative stress $(50 \mathrm{mM}$ $\mathrm{H}_{2} \mathrm{O}_{2}$ ), induced by preincubation at $37^{\circ} \mathrm{C}$ for $60 \mathrm{~min}$

Yeast cells from CAI.4 and tps1/tps1 strains were grown in YPgal at $28{ }^{\circ} \mathrm{C}$ and harvested in exponential phase $\left(\mathrm{OD}_{600} 1 \cdot 5\right)$. A sample maintained at $28^{\circ} \mathrm{C}$ was used as control.

Numbers in parentheses represent the relative activity normalized to the control for each parameter, taking the control treatment as $1 \cdot 0$.

\begin{tabular}{|c|c|c|c|c|c|c|}
\hline \multirow[t]{2}{*}{ Treatment } & \multicolumn{2}{|c|}{ Trehalose* } & \multicolumn{2}{|c|}{ T-6P synthase $\dagger$} & \multicolumn{2}{|c|}{ Neutral trehalase $\neq$} \\
\hline & CAI.4 & tps $1 /$ tps 1 & CAI.4 & tps1/tps1 & CAI.4 & tps1/tps1 \\
\hline Control & $3.9(1 \cdot 0)$ & $2 \cdot 5(1 \cdot 0)$ & $10 \cdot 4(1 \cdot 0)$ & $<2 \cdot 0$ & $17 \cdot 4(1 \cdot 0)$ & $20 \cdot 4(1 \cdot 0)$ \\
\hline $37^{\circ} \mathrm{C}$ & $4 \cdot 8(1 \cdot 2)$ & $3 \cdot 0(1 \cdot 2)$ & $14.6(1 \cdot 4)$ & $<2 \cdot 0$ & $18 \cdot 6(1 \cdot 1)$ & $19 \cdot 3(0 \cdot 9)$ \\
\hline $\mathrm{H}_{2} \mathrm{O}_{2}$ & $11 \cdot 8(3 \cdot 0)$ & $1.6(0 \cdot 6)$ & $25 \cdot 0(2 \cdot 4)$ & $<2 \cdot 0$ & $12 \cdot 5(0 \cdot 7)$ & $14 \cdot 7(0 \cdot 7)$ \\
\hline $37^{\circ} \mathrm{C} \rightarrow \mathrm{H}_{2} \mathrm{O}_{2}$ & $9.9(2.5)$ & $2 \cdot 6(1 \cdot 0)$ & $21 \cdot 8(2 \cdot 1)$ & $<2 \cdot 0$ & $15 \cdot 9(0.9)$ & $16 \cdot 6(0 \cdot 8)$ \\
\hline
\end{tabular}

* nmol trehalose $(\mathrm{mg} \text { wet } \mathrm{wt})^{-1}$.

† nmol trehalose $\min ^{-1}$ (mg protein $)^{-1}$.

$\ddagger$ nmol glucose $\min ^{-1}$ (mg protein $)^{-1}$.

further upshift to $42{ }^{\circ} \mathrm{C}$ clearly promoted the carbohydrate storage (Argüelles, 1997; Zaragoza et al., 1998).

When similar cultures were pretreated for $60 \mathrm{~min}$ at $37^{\circ} \mathrm{C}$, they improved their capacity to withstand a further challenge with $50 \mathrm{mM} \mathrm{H}_{2} \mathrm{O}_{2}$, the protective effect being particularly evident with respect to the samples directly submitted to the oxidative stress (Fig. 3). Measurements of trehalose in these conditions revealed that $\mathrm{H}_{2} \mathrm{O}_{2}$ caused an accumulation of intracellular disaccharide, which was not prevented by previous incubation at $37^{\circ} \mathrm{C}$ (Table 3). Simultaneous determination of $\mathrm{T}-6 \mathrm{P}$ synthase and neutral trehalase activities confirmed this was due to the activation of trehalose biosynthesis and the concomitant inhibition of the trehalose hydrolysis (Table 3). The lack of trehalose synthesis in $t p s 1 / t$ t 1 (Table 3 ) cells reflects a small role, if any, for trehalose in the acquired tolerance to 


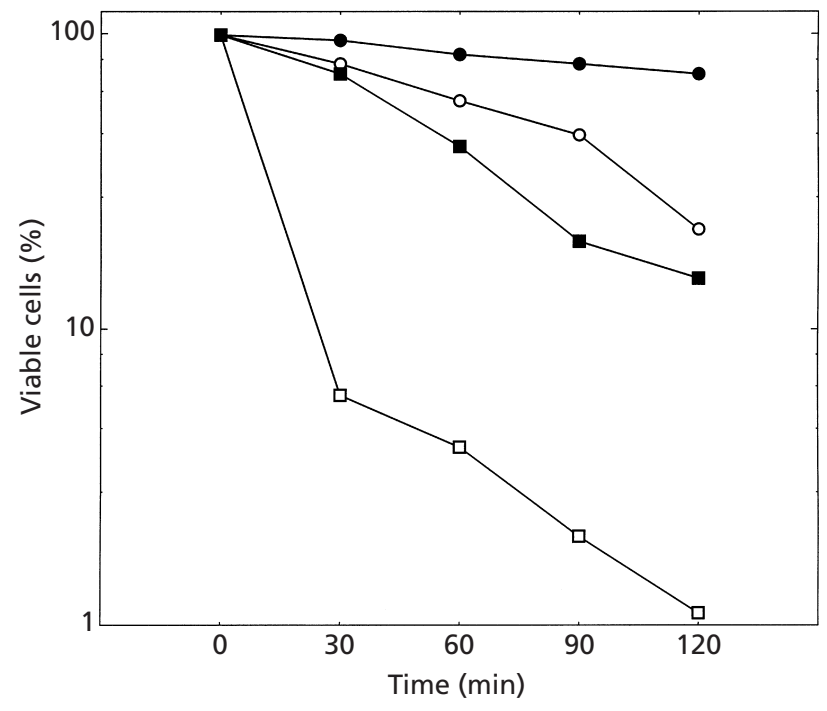

Fig. 3. Acquisition of 'cross-tolerance' in blastoconidia from $C$. albicans. Exponential cultures growing on YPgal from strains CAl.4 (O, O) and tps1/tps1 $(\square, \square)$ were maintained at $28{ }^{\circ} \mathrm{C}$ and directly exposed to $50 \mathrm{mM} \mathrm{H}_{2} \mathrm{O}_{2}$ (white symbols) or transferred at $37^{\circ} \mathrm{C}$ for 60 min (black symbols) before being submitted to oxidative stress. The percentage of survival was referred to an identical, untreated sample (100\% viability). For other details see Fig. 2.

oxidative stress. As pointed out by Lewis et al. (1997), $\mathrm{H}_{2} \mathrm{O}_{2}$ tolerance might be used as a suitable marker for the general assessment of stress tolerance in yeast.

\section{DISCUSSION}

In the yeast $S$. cerevisiae, protective stress responses are strictly dependent on a number of factors and pathways, including a large accumulation of intracellular trehalose and a pronounced expression of the heat-shock proteins family (Hsps) (Estruch, 2000). Although trehalose and some Hsps (e.g. Hsp104) are synthesized simultaneously and have a synergistic effect (Elliot et al., 1996), these components appear to play different roles during protein denaturation, preventing protein aggregation and further repair of damaged protein during the stress challenge (Singer \& Lindquist, 1998).

Heat shock elicits in yeast a complex response that involves the coordinated action of Hsp104, Hsp70 and trehalose accumulation (Estruch, 2000). By contrast, protection against moderate or high osmolarity mainly depends on the high osmolarity glycerol (HOG) pathway, which controls the osmotic induction of glycerolsynthesizing enzymes (Brewster et al., 1993). As regards oxidative stress, the capacity to withstand the deleterious effect of ROS requires both enzymic (catalase or superoxide dismutase) and non-enzymic (gluthatione and thioredoxin) components (Jamieson, 1998; Estruch, 2000).

Data obtained here support the hypothesis that trehalose is needed as protectant for growing C. albicans blastoconidia directly submitted to a severe oxidative treatment (higher than $10 \mathrm{mM} \mathrm{H}_{2} \mathrm{O}_{2}$ ) (Figs 1 and 2). The $\mathrm{H}_{2} \mathrm{O}_{2}$-sensitive phenotype shown by tps1/tps 1 cells was efficiently suppressed by overexpression of the TPS1 gene (Figs 1 and 2). However, direct exposure to oxidants promotes a lower degree of trehalose accumulation than other stress conditions. In a previous study (Jamieson et al., 1996), trehalose synthase was not considered as a specific antioxidant enzyme. The storage of the disaccharide, however, appears to be largely dispensable during the adaptive response triggered by a previous incubation with a low non-lethal concentration of $\mathrm{H}_{2} \mathrm{O}_{2}$, the degree of tolerance being roughly equivalent in both wild-type and tps1/tps1 cultures (Fig. 2, Table 2). Furthermore, although C. albicans displays a cross-tolerance protective mechanism that increases the resistance to $\mathrm{H}_{2} \mathrm{O}_{2}$ induced by mild heat exposure $\left(37^{\circ} \mathrm{C}\right)$, this occurs with no specific change in trehalose metabolism (Fig. 3, Table 3).

Therefore, present knowledge suggests that although trehalose must be considered one of the principal protective factors against ROS, other elements must be involved in the response to oxidative stress. Exposure to moderate stress seems to activate an alternative pathway, which would build up the resistance, even when a further severe stress is applied. However, when nonadapted cells are subjected to an intense stress, the ability to synthesize trehalose appears to be essential. Consequently, we propose that the response to ROS involves two different steps: a first step would be triggered immediately by the direct stress and requires the intracellular accumulation of trehalose, while the second would need some time before being fully operative, and be dependent on (a) pathway(s) as yet unidentified. In the absence of trehalose synthesis, this second mechanism would become operative after a previous mild exposure to a non-lethal stress.

The study of oxidative stress responses in C. albicans may have important clinical repercussions in assessing the progress of in vivo infections and the respiratory defensive mechanism of phagocytes. Thus, the formation of ROS and other oxidants by phagocytes plays an essential function in combating fungal infections (Murphy, 1991) and the effective antifungal effect of azole drugs on ergosterol biosynthesis is in part due to the sensitization of C. albicans to the reactive oxygendependent microbicidal system produced by macrophages (Shimokawa \& Nakayama, 1992). In this context, our preliminary results suggest that the tps1/ tps1 mutant displays greater sensitivity to the phagocytosis brought about by mouse macrophages than its counterpart CAI.4 (results not shown), which might explain the low rate of infectivity exhibited by tps1/tps1 cells when inoculated in mice (Zaragoza et al., 1998).

\section{ACKNOWLEDGEMENTS}

F.A.-P. and O.Z. contributed equally to this paper. We thank Drs C. Gancedo and J. M. Gancedo (CSIC, Madrid) for their 
continuous scientific help and warm support. F. Alvarez-Peral received a grant from Ingeniería Urbana (Grupo Cespa, Spain). O. Zaragoza was partially supported by a Fellowship from the Spanish Plan de Formación de Personal Investigador in the frame of grant PB97-1213-C02 from the Spanish DGES to J. M. Gancedo. This work was supported in part by the Research Project ALI99-1224-C02-02 from CICYT (Spain).

\section{REFERENCES}

Argüelles, J. C. (1997). Thermotolerance and trehalose accumulation induced by heat shock in yeast cells of Candida albicans. FEMS Microbiol Lett 146, 65-71.

Argüelles, J. C. (2000). Physiological roles of trehalose in bacteria and yeast: a comparative analysis. Arch Microbiol 174, 217-224.

Argüelles, J. C., Rodríguez, T. \& Alvarez-Peral, F. J. (1999). Trehalose hydrolysis is not required for human serum-induced dimorphic transition in Candida albicans: evidence from a tps1/tps1 mutant deficient in trehalose synthesis. Res Microbiol 150, 521-529.

Berlett, B. S. \& Stadtman, E. R. (1997). Protein oxidation in aging, disease and oxidative stress. J Biol Chem 272, 20313-20316.

Blázquez, M. A., Stucka, R., Feldmann, H. \& Gancedo, C. (1994). Trehalose-6-P synthase is dispensable for growth on glucose but not for spore germination in Schizosaccharomyces pombe. J Bacteriol 176, 3895-3902.

Brewster, J. L., de Valoir, T., Dwyer, N. D. \& Gustin, M. C. (1993). An osmosensing transduction pathway in yeast. Science 259, 1760-1763.

Brown, A. J. P. \& Gow, N. A. R. (1999). Regulatory networks controlling Candida albicans morphogenesis. Trends Microbiol 7, 333-338.

Coleman, D. C., Bennett, D. J., Sullivan, P. J., Gallagher, M. C., Henman, D. B., Shanley, D. \& Russell, R. J. (1993). Oral Candida in HIV infection and AIDS: new perspectives and new approaches. Crit Rev Microbiol 19, 61-82.

Cutler, J. E. (1991). Putative virulence factors of Candida albicans. Annu Rev Microbiol 45, 187-218.

Elliot, B., Haltiwanger, R. S. \& Fuchter, B. (1996). Synergy between trehalose and hsp104 for thermotolerance in Saccharomyces cerevisiae. Genetics 144, 923-933.

Ernst, J. F. (2000). Transcription factors in Candida albicans environmental control of morphogenesis. Microbiology 146, 1763-1774.

Estruch, F. (2000). Stress-controlled transcription factors, stressinduced genes and stress tolerance in budding yeast. FEMS Microbiol Rev 24, 469-486.

Fonzi, W. A. \& Irwin, M. Y. (1993). Isogenic strain construction and gene mapping in Candida albicans. Genetics 134, 717-728.

Hottiger, T., Schmutz, P. \& Wiemken, A. (1987). Heat-induced accumulation and futile cycling of trehalose in Saccharomyces cerevisiae. J Bacteriol 169, 5518-5522.

Jamieson, D. J. (1998). Oxidative stress responses of yeast Saccharomyces cerevisiae. Yeast 14, 1511-1527.

Jamieson, D. J., Stephen, D. W. S. \& Terriere, E. C. (1996). Analysis of the adaptive oxidative stress response of Candida albicans. FEMS Microbiol Lett 138, 83-88.

Kurtz, M. B., Cortelyou, M. W. \& Kirsch, D. R. (1986). Integrative transformation of Candida albicans using a cloned Candida ADE2 gene. Mol Cell Biol 6, 142-149.

Lewis, J. G., Learmonth, R. P. \& Watson, K. (1995). Induction of heat, freezing and salt tolerance by heat and salt shock in Saccharomyces cerevisiae. Microbiology 141, 687-694.

Lewis, J. G., Learmonth, R. P., Attfield, P. V. \& Watson, K. (1997). Stress co-tolerance and trehalose content in baking strains of Saccharomyces cerevisiae. J Ind Microbiol Biotechnol 18, 30-36.

Lo, H. J., Köhler, J. R., DiDomenico, B., Loebenberg, D., Cacciapuoti, A. \& Fink, G. R. (1997). Nonfilamentous Candida albicans mutants are avirulent. Cell 90, 939-949.

Mager, W. H. \& Moradas-Ferreira, P. (1993). Stress response of yeast. Biochem J 290, 1-13.

Molero, G., Díez-Orejas, R., Navarro, F., Monteoliva, L., Pla, J., Gil, C., Sanchez-Perez, M. \& Nombela, C. (1998). Candida albicans: genetics, dimorphism and pathogenicity. Int Microbiol 1, 95-106.

Murphy, J. W. (1991). Mechanisms of natural resistance to human pathogenic fungi. Annu Rev Microbiol 45, 509-538.

Nwaka, S. \& Holzer, H. (1998). Molecular biology of trehalose and the trehalases in the yeast Saccharomyces cerevisiae. Prog Nucleic Acids Res Mol Biol 58, 199-224.

Nwaka, S., Kopp, M. \& Holzer, H. (1995). Expression and function of the trehalase genes NTH1 and YBR106 in Saccharomyces cerevisiae. J Biol Chem 270, 10193-10198.

Odds, F. C. (1988). Candida and Candidiosis, a Review and Bibliography. London: Baillière Tindall.

Odds, F. C. (1994). Candida species and virulence. ASM News 60, 313-318.

Plá, J., Pérez-Díaz, M., Navarro-García, F., Sánchez, M. \& Nombela, C. (1995). Cloning of Candida albicans HIS1 gene by direct homologous complementation of a histidine auxotroph using an improved double-ARS shuttle vector. Gene 165, 115-120.

Sambrook, J., Fritsch, E. F. \& Maniatis, T. (1989). Molecular Cloning: a Laboratory Manual. Cold Spring Harbor, NY: Cold Spring Harbor Laboratory.

Shepherd, M. G., Poulter, R. M. \& Sullivan, P. A. (1985). Candida albicans: biology, genetics and pathogenicity. Annu Rev Microbiol 39, 579-614.

Shimokawa, O. \& Nakayama, H. (1992). Increased sensitivity of Candida albicans cells accumulating 14 alpha-methylated sterols to active oxygen: possible relevance to in vivo efficacies of azole antifungal agents. Antimicrob Agents Chemother 36, 1626-1629.

Singer, M. A. \& Lindquist, S. (1998). Multiple effects of trehalose on protein folding in vivo and in vitro. Mol Cell 1, 639-648.

Storz, G., Christman, M. F., Sies, H. \& Ames, B. N. (1987). Spontaneous mutagenesis and oxidative damage to DNA in Salmonella typhimurium. Proc Natl Acad Sci U S A 84, 8917-8921.

Thevelein, J. M. (1996). Regulation of trehalose metabolism and its relevance to cell growth and function. In The Mycota, vol. 3, pp. 395-414. Edited by R. Brambl \& G. A. Marzluf. Heidelberg: Springer.

Werner-Washburne, M., Braun, E., Johnston, G. C. \& Singer, R. A. (1993). Stationary phase in the yeast Saccharomyces cerevisiae. Microbiol Rev 57, 383-401.

Wiemken, A. (1990). Trehalose in yeast, stress protectant rather than reserve carbohydrate. Antonie Leeuwenhoek 58, 209-217.

Zähringer, H., Burgert, M., Holzer, H. \& Nwaka, S. (1997). Neutral trehalase Nth1p of Saccharomyces cerevisiae encoded by the NTH1 gene is a multiple stress responsive protein. FEBS Lett 412, 615-620.

Zähringer, H., Thevelein, J. M. \& Nwaka, S. (2000). Induction of neutral trehalase $N t h 1$ by heat and osmotic stress is controlled by 
STRE elements and Msn2/Msn4 transcription factors: variations of PKA effect during stress and growth. Mol Microbiol 35, 397-406.

Zaragoza, O., Blázquez, M. A. \& Gancedo, C. (1998). Disruption of the Candida albicans TPS1 gene encoding trehalose-6P-synthase impairs formation of hyphae and decreases infectivity. J Bacteriol 180, 3809-3815.

Received 26 March 2002; accepted 11 April 2002. 